\title{
COLONIALITY AT LARGE
}

LATIN AMERICA AND

THE POSTCOLONIAL DEBATE

A book in the series

LATIN AMERICA OTHERWISE: LANGUAGES, EMPIRES, NATIONS

SERIES EDITORS:

Walter D. Mignolo, Duke University Irene Silverblatt, Duke University Sonia Saldívar-Hull, University of Texas, San Antonio 



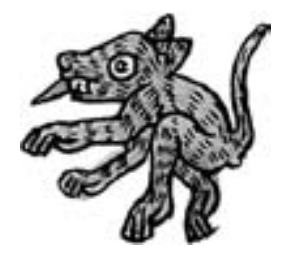

\section{COLONIALITY AT LARGE}

Latin America and the Postcolonial Debate

EDITED BY

Mabel Moraña,

Enrique Dussel, and

Carlos A. Jáuregui 
(C) 2008

Duke University Press

All rights reserved

Printed in the

United States of America

on acid-free paper $\infty$

Designed by Jennifer Hill

Typeset in Quadraat by

Keystone Typesetting, Inc.

Library of Congress

Cataloging-in-Publication

information and republication acknowledgments appear on the last printed pages of this book. 